\title{
RESISTANCE FOR TRUTH IN NICOLA YOON'S NOVEL EVERYTHING, EVERYTHING
}

\author{
Siska Dewi Rahayu, Sri Wulan \\ English Department, Faculty of Literature, \\ Universitas Islam Sumatera Utara, Medan, Indonesia \\ e-mail: siskadewi181@gmail.com
}

\begin{abstract}
This study is concerned with the resistance of the protagonist. The protagonist, Madeline Whittier has a great bravery to resist rules and fear to find the truth although she is still teenager. The protagonist's form of resistance and truth are formulated in the statement of the problem. Various theories are adapted to support the analysis, and one of which was proposed by Eric and Jay in theirs book Resistance and Persuasion. The method used in this study is qualitative. The method gives a significant portrayal of the protagonist's resistance. The findings of this study are two forms of resistance done by the protagonist, i.e. resisting her mother's rules and resisting her own fear. Such resistance results in the truth that the protagonist discovers. First is about her true disease, and second her mother's lies to her for seventeen years. In conclusion, the protagonist conducts resistance to find truth of her own life.
\end{abstract}

Keywords: resistance, truth, teenager, SCID, everything

\section{Introduction}

Everything, Everything is a novel written by Nicola Yoon and the illustration by her husband. This novel tells about the resistance of a teenager to find a truth about herself. For seventeenth years, Madeline lived in a bubble called in her room in her house. Never breathe oxygen which blend with living tress, never feels her green grass on her feet, never comes out of the door of her house. She has an illness that if she interacts just a few seconds with the outside world, she can die. People are gifted with resistance. Resistance is highly needed to face challenges in future life.

Resistance is a movement of rebellion in achieving certain goals. The hardest of resistance is to get risks. Some people avoid and do not get and take risks. When people have resistance, everything will be easy to do for them. Resistance is encouragement to fight fear and motivation to get and take risks. According to Messer (2002), resistance is unwillingness to achieve insight about the real nature of one's thoughts or feelings. Basically resistance is referred to as bravery. The element becomes the important things in reality to make someone do resistance for what he/she thinks true, right, and fair.

Truth is something that is true without a lie even if only a little. The truth is very much interpreted. Truth is one of the important things in life. In new era, the truth is quite difficult to find in daily life. Truth can be said because of the compatibility between the meanings meant by an opinion and facts.

This novel studied is concerned with the resistance of a girl to find the truth of herself. Although she is still teenager, she is brave enough to make a resistance to her own life. Initially, she wants to be free like others but the situation cannot be allowed. 
The protagonist's resistance is created by the author of the novel Nicola Yoon, to inspire her daughter about what she has to do to find truth in her life. Finally, this study is to discover the protagonist's resistance and the truth revealed in the novel.

\section{Literature Review}

Resistance occurs because of certain events that make someone dare not to obey the rules or directives given. It also has the same idea as the theory below:

"Psychological resistance is broad term, with a long and varied history, that refers to a variety of specific events. The term has been used to refer to the noncompliance with a directive" (Newman, 2002: 157).

Resistance has acquired a dual definition in psychology. On the one hand, it defines an outcome: the outcome of not being moved by pressures to change. On the other hand, it identifies a motivational state: the motivation to oppose and counter pressures to change.

According to Arkowitz (2002: 219), resistance is the feeling of ambivalence about change. Resistance to persuasion is familiar to anyone who has offered advice or counselling, delivered a sales pitch, or tried to enlist others in a plan of action. The clear core of the definition of resistance is that it is a reaction against change. It becomes evident in the presence of some pressure for change. Although resistance is a response to pressures for change, the source of resistance is sometimes attributed more to the person, and sometimes it is attributed more to the situation.

"Resistance has transformed into a dominant conceptual framework in anthropology. Resistance has also become an attractive topic in light of anthropology's relatively recent focus on social inequality, power, and cultural hegemony". (Seymour, 2006: 303).

This has opened up the concept of resistance in anthropology, generating diverse works relating to human opposition to various forms of power and dominance, in a myriad of differing context.

McAdam, Tarrow and Tilly argued that Scott's concentration on individual resistance 'provided little purchase on the question of when these low-level resentments would lead to mobilization and collective action and when they would remain at the level of individual resentment.' (McAdam et al: 1997) in Wing-Chung Ho's journal: 2011.

The analysis is based on the psychological and anthropological concept. Resistance requires influence from internal factors (Psychology) and the environment or other people or external factors as the result of social interaction (Anthropology).

\subsection{Four Faces of Resistance}

As we think about the nature of resistance, we identify four different but probably related faces. We think of these not as different kinds of resistance, but as different perceptual stances toward it, much the same way an object viewed from four directions may present varied retinal projections but still be seen as the same entity. .

a. Reactance

One face of resistance is the reactance described by Brehm (1966) in Eric S \& Jay A, 2004: 7 (Ed). This face of resistance recognizes the influence attempt as an 
integral element of resistance. Reactance is initiated only when the influence is directly perceived and when it threatens a person's choice alternatives. This view of resistance also emphasizes the affective ("I don't like it!") and motivational ("I won't do it!") sides of resistance.

\section{b. Distrust}

Another face of resistance spotlights the target of change, and it reveals a general distrust of proposals in Eric S \& Jay A, 2004: 7 (Ed). People become guarded and wary when faced with a proposal, offer, or message to change. They wonder what the motive behind the proposal might be, what the true facts are. This face of resistance underlies both affective ("I don't like it!") and cognitive ("I don't believe it!") reactions to influence. We chose to describe this face as "distrust" rather than "paranoia" because some degree of this wariness seems legitimate. The persuader's goals may be divergent from the target's goals and may, in fact, be exploitive.

\section{c. Scrutiny}

A third face of resistance is a general scrutiny that influence, offers, or requests create. When people become aware that they are the target of an influence attempt, a natural reaction is to attend more carefully and thoughtfully to every aspect of the situation (Langer: 1989; Petty \& Cacioppo: 1986) in Eris S \& Jay, 2004: 7 (Ed). This is a form of resistance that puts emphasis on the proposal itself. The careful scrutiny of the proposal means that each point is examined more carefully and questioned more thoroughly. The strengths of an argument are appreciated and accepted, and to that extent the proposal is believed. But, the weaknesses of an argument are exposed, evaluated, and countered, and to that extent, the proposal is rejected. Several chapters in this volume emphasize this scrutiny face of resistance and illustrate the many ways that this primarily cognitive element ("I don't believe it!") works. Wegener et al.'s chapter on multiple routes to resistance to persuasion discusses the many, often subtle ways this form of resistance works. The scrutiny face is also discussed in the chapter by Johnson et al. (this volume) on the power of positive thinking and in the chapter by Haugtvedt et al. (this volume), which explores resistance in consumer psychology.

\section{Inertia}

A fourth face of resistance might be called inertia. This is a face that is not reactant to the proposer or the proposal, and it does not necessarily lead to greater scrutiny, distrust, or reactance. Inertia is a quality that focuses more on staying put than on resisting change. It is one face of the great equilibrium motive (Heider: 1946) in Eric S \& Jay A, 2004: 7-8 (Ed), that attempts to keep the attitude system in balance. To the extent that a request, an offer, or a persuasive message asks for change in affect, behaviour, or belief, the inertia of personality and attitude frustrates that change. However, this form of resistance has more in common with the drag of an anchor than with the antagonism of the provoked.

\subsection{Truth}

Truth is a coherent and consistent statement with previous statements that are considered correct. Humans are always searching for the truth, if humans understand the truth, their natural behaviour motivated to carry out that truth. 
"Truth is fidelity to objective reality. This theory is adopted by realist course. The vanguard of Plato, Aristotle was further developed by Ibn Sina, Thomas Aquinas in the scholastic century, and by Bertrand Russell in the modern century". (Keraf, 2001: 43).

It is clear that the truth is the suitability of statements with facts that harmonize with the reality and harmonize with the actual situation. The theory also has a same idea as the theory by Bakhtiar (2010: 1-5), truth is that which corresponds to fact that harmonize with reality that is in harmony with the actual situation.

According to Lorens, Bagus (2002: 212), truth shows the relationship between what we express with what we feel. Sometimes we think that what we feel is a truth that people should know, and we are trying to express it without any hesitation. The theory also has a same idea as the theory by Jujun S. Suriasumantri (2010: 78), the truth is a statement without hesitation.

\section{Research Method}

This study applies qualitative method. According to Sugiyono (2013: 12), the qualitative method is used to research for natural place, and research does not make treatment, because researchers in collecting data which is based on the views of data sources, and not on views of researchers. It is clear that a qualitative research is a systematic subjective approach in collecting data based on data views to describe life experiences and give them meaning. Qualitative method here gives a portrayal of the significance of resistance which constitues a kind of social challenge. Therefore, it is a suitable method used in this research. It is also in line with the idea claimed by Setiawan, Barus, and Pawiro (2017) in which they state that qualitative descriptive method is an appropriate method as it gives detailed points of some social events.

\section{Discussion}

\subsection{The Form of Protagonist's Resistance \\ 4.1.1 Resisting Her Mother's Rule}

There are some rules from the protagonist's mother, one of which is not to lie in any case. This is the first form resistance of the protagonist which exists in the novel. She lies to her mother at the first time in her life. In the novel, lying is clearly depicted as quoted in the following:

"Carla gives me a sharp look. I've never lied to my mom. I've never had a reason and I don't think I know how to. But something tells me what I need to do." (Yoon, 2015: 27).

It shows a view about the protagonist at the time. She lies at the first time. She never lies to her mother before. The first reason about her lies is that she does not want her mother to feel worried about her because she does not complete her assignment yet. In another situation, she lies for the second time to her nurse, Carla. She is more courageous to lie. The quotation below shows how she lies to Carla.

"What's so interesting on that laptop?" she asks. God. She definitely knows. I draw my chair closer to the desk and place my sandwich on the laptop. "Nothing." I take a bite of the sandwich. It's Turkey Tuesday." (Yoon, 2015: 60) 
It shows that she is worried and afraid if Carla will know about her secret because she has talked with Olly via email.

For several days, she becomes convinced that what she doing is fine. It is time for her dare to talk to Carla about her plan.

"You know I don't like saying no to you. You're a good girl." I rush right through this opening. "He'd get decontaminated and sit across the room, far, far away from me and only for fifteen minutes. Thirty minutes at the most."She shakes her head, but it's not a firm shake. "It's too risky. And your mother would never allow it." "We won't tell her," I say instantly. She gives me a sharp, disappointed look. "Do you girls really find it so easy to lie to your mamas?" (Yoon, 2015: 66)

It shows that she wants Carla to hide the plan from her mother. Her plan is to meet Olly without knowing her mother. That is the proof that she opposes her mother's rule by lying.

In other chance, she does something else what her mother forbids her to do. Here a quotation about that:

"In two weeks my skin will have no memory of Olly's hand on mine, but my brain will remember. We can have immortality or the memory of touch. But we can't have both" (Yoon, 2015: 122).

The condition seems to allow her to do something about the psychological activity however, her mother gives the rule. Her mother really bans Madeline to have any relationship with other people. Moreover, she is prohibited to fall in love with Olly. Her mother does not really want her to be contaminated with strangers due to Madeline's illness. Unfortunately, the situation allows Madeline to always meet Olly without knowing her mother. This shows that Madeline resists her mother's rule, not having relationship with Olly.

In other situation, after her mother knows what Madeline hides something from her, her mother fires her nurse, Carla, and she gets a punishment about her failure. She snaps her mother.

"I am not lonely, Mom," I snap. "I am alone. Those are different things.

"She flinches but doesn't retreat. Instead, she lets go of whatever she is holding and caresses my cheek until I meet her eyes. "I know, baby girl." Her hands are behind her back again. "Maybe now is not a good time. Do you want me to go? "She's always so reasonable and understanding. It's hard to be angry with her. "No, it's OK. I'm sorry. Stay." I pull my legs up, making room for her. "What are you hiding?" I ask. (Yoon, 2015: 158-159)

It shows that she gets frustration because of her mother. She wants to get angry but she cannot do that. In this quotation, it shows she already feels suspicious, and distrusts what her mother hide from her. This urges Madeline to resist her mother's rule since she starts to think that her mother is overprotective and it makes her uncomfortable.

The protagonist's resisting her mother's rule is very prominent. This can be proven in the quotation: 
"I don't know, Mom. I don't know what I'm doing only that I have to. Sometimes I wish I could go back to the way I was before, before I knew anything. But I can't. I'm sorry. Forgive me. I love you. Maddy.’(Yoon, 2015: 169)

The protagonist writes the letter for her mother. She wants to try something different in her life, and wants to breathe freely. She will go to Hawaii with Olly, her boyfriend. And finally Madeline travels to Hawaii with Olly without her mother's permission. She just leaves her mother a letter and she does not want her mother to follow her to Hawaii. She tells her mother that she is fine with Olly. This clearly proves that the protagonist resists her mother's rule.

Besides, another action of resistance from the protagonist is that she gets out of her rouse for the first time without her mother's permission, as it is seen in the following:

"I'm in Olly's garden. The air is full, ripe with scent-flowers, earth, my expanding fear. I store it away in my lungs. I toss pebbles at his window, willing him to come out." (Yoon, 2015: 171)

She does it because she feels uneasy about Olly who is in a bad condition. She tries to help him. What she did is against her mother's rule in her life. Madeline never goes out of the house. She just stays at home for 17 years. But, after meeting Olly, she becomes courageous to break her mother's rule.

Those quotations, above show that the protagonist resists her mother's rules. And these are caused by prominently her meeting and love to Olly, the only boy whom she befriends with and falls in love with from the first time. The protagonist does not obey her mother's rule anymore. Unfortunately, the protagonist does such resisting to prove something that she believes is true.

\subsubsection{Resisting Her Own Fear}

Besides resisting her mother's rule, there is another thing she resists in her life. She is against her fear and worry about her disease. In the novel, there are the quotes about the resistance of her own fear below:

"I'm hiding in my usual spot behind the curtain when I suddenly no longer want to hide. I turn on the lights and go back to the window. I don't even bother to take a deep breath." (Yoon, 2015: 31)

She wants to see Olly outside. She is always hiding behind the window, because she is afraid and worried if Olly can realize her. But in this quotation, it shows that she already has a little encouragement to resist her fear.

"I think of Olly, decontamination-cold and waiting for me. He's the opposite of all these things. He's not safe. He's not familiar. He's in constant motion. He's the biggest risk I've ever taken" (Yoon, 2015: 69).

It shows that the protagonist feels worried at the first. She is worried if her decision will be a big risk. She is afraid of anything especially, meeting Olly, but she still does it.

After she succeeded against her fear at the first time, her confidence is getting stronger. It is indicated in the quotation below: 
"I tell myself it's OK. I didn't get sick after the last time I saw him, and he knows the rules-no touching, full decontamination treatment, no visit if he even suspects he could get sick in the next few days. I tell myself there's no harm in lying to my mom. I tell myself I won't get sick. I tell myself there's no harm in friendship. That Carla is right, and love can't kill me.”(Yoon, 2015: 94)

It proves that the protagonist is getting higher confident against her fear. She believes that nothing will happen. At the last time she meets Olly, she does not feel the negative impact about the disease of her body.

At one point, the protagonist sees Olly in a bad condition. It happens at the garden of Olly's house, and she sees him from the window of her room.

"The urge to go to him fills me up like it did the last time. I want to go to

him. I need to go to him, to comfort him, to protect him." (Yoon, 2015:

It shows that the protagonist has been influenced by her boyfriend to do a resistance. She has the urge to help Olly. The urge is to resist her own fear to leave the house.

The encouragement fills her heart. She wants to get out of the house to help Olly regardless of the consequences she will get, as verified in the following:

I'm in Olly's garden. The air is full, ripe with scent-flowers, earth, my expanding fear. I store it away in my lungs. I toss pebbles at his window, willing him to come out. "What are you doing out here? Are you all right? Is something wrong? Is your mom OK?" I'm all bravado. "I'm fine. She's fine. I'm running away." (Yoon, 2015: 171-172)

It shows that the protagonist is courageous to take a risk. She finally manages to throw away her fear of leaving the house for the first time.

After she gets courageous to against her fear for the first time, she wants to try something different that she has never done before in her life. She wants to go to Hawaii with her boyfriend without knowing her mother.

"Mads, be serious. We can't go to Hawaii." "Why not? I got us plane tickets. I booked us a hotel." We're sitting in Olly's car in the driveway. He puts the key in the ignition, but doesn't turn it. He pulls his forehead off the wheel, but still stares straight ahead not meeting my eyes. "What if something happens to you?" "Nothing will." "But what if it does?" "I have the pills, Olly. They're going to work.” (Yoon, 2015: 178-179).

It seems that the protagonist tries to convince her boyfriend that nothing will happen to her. Even though, she actually feels anxious and afraid about her disease. She lies that she has the pills to control her disease.

When they are going to Hawaii together, they spend time like a couple in general. But Olly is still worried about the protagonist's condition. The quotation below shows this:

"He looks at me, a nonbeliever confronted with, if not evidence, then at least the possibility of God. He pulls me into his arms and we're wrapped around each other, his face buried in my hair and my face 
pressed into his chest, no daylight between our bodies. "Don't die," he says. "I won't," I say back." (Yoon, 2015: 193)

It proves that the protagonist resists her fear about death. Even though she does not know what will happen later, but she says to her boyfriend if she is okay and will not die.

She is already away from her house. Her dream is seeing the world. She has never been to go outside for seventeenth years.

"Because there's no denying it now. I'm in the world. And, too, the world is in me." (Yoon, 2015: 196)

The quotation shows that the protagonist feels thankful because she gets a chance to see the world. She does not believe that she can do something different in her life. Against her fear, it is one of goals in her life. Fear to see the world is something hard to do for her, but she can do it.

An opportunity makes her believe that she can enjoy her life a little no matter what happens later, as it is seen in the following:

"Listening to the magnified sound of my own breath is peaceful and strangely euphoric. I'm being reassured with every breath that I'm more than just alive. I'm living." (Yoon, 2015: 208)

In this quotation, it shows that the protagonist feels happy because she can breathe freely. She believes that life must be enjoyed freely without having limitation. She can resist her fear about by going away from house to enjoy her living.

\subsection{The Truth Found in the Novel}

\subsubsection{The Truth of Her Disease}

There is so much truth found by the protagonist in the novel after she does resistance for her life. She finds the secret. The secret is the truth about her disease which she does not know before.

"I felt it was important to contact you directly. You need to know that I've studied your case very closely. I don't believe you have, or have ever had, SCID. I know this must be a shock. I've attached quite a few test results here and I recommend that you get a second (and a third) opinion. I believe that you should get another physician besides your mother to verify my findings. Physicians should never practice on their families. It is my medical opinion that in Hawaii last month you had an episode of myocarditis triggered by a viral infection. I believe that your immune system is Especially, fragile given what I could surmise about the nature of your upbringing." (Yoon, 2015: 262-263)

It seems that the protagonist gets an email from the doctor who treats her when her disease is recurred in Hawaii. The doctor says that she does not believe if the protagonist is hit by SCID (Severe Combined Immunodeficiency). The doctor's diagnose is that the protagonist is only exposed to muscle inflammation triggered by infection.

After the protagonist gets an email from the doctor. She is shocked and suspicious of her mother. She thinks that all this time her mother lies to her. 
"And then her record keeping becomes less meticulous. I find a printout about RSV from the web. She circled a section that explains that RSV (Respiratory Syncytial Virus) is more severe in people with compromised immune systems. I find a photocopy of the first page of an article on SCID from a medical journal. Her scrawls in the margins are illegible. After that there's a single visit to an allergist and then visits to three different immunologists. Each concludes that no illness was found." (Yoon, 2015: 272-273)

It shows that the protagonist searches for evidence about her disease in her mother's room, but she does not get any proof to declare that she has SCID. It is clear that the protagonist does a scrutiny for find the truth about her disease.

Finally, the protagonist meets a specialist of SCID to find a concrete evidence of her disease though she has already known the truth.

"I've gone over these results time and again. I had my colleagues check to be absolutely certain. You're not sick, Ms. Whittier."He stops and waits for me to react. I shake my head at him. "I already know," I say again. "Yes. You must have some questions for me." "Why did I get sick in Hawaii? "People get sick, Madeline. Normal healthy people get sick all the time." "But my heart stopped." "Yes. I suspect myocarditis. I spoke with the attending in Hawaii as well. She suspected the same thing. Basically at some point in your past you probably had a viral infection that weakened your heart. Had you been experiencing any chest pain or shortness of breath when you were in Hawaii?" "Yes," I say slowly, remembering the squeezing of my heart that I'd wilfully ignored. "Well, myocarditis seems like a likely candidate."I don't have any other questions, not for him anyway. I stand. "Well, thank you very much, Dr. Chase" (Yoon, 2015: 282-283)

This quotation shows that the protagonist is not exposed to SCID. She is only exposed to inflammation of the heart muscle because the immune system is less developed. Therefore, it is easy for her to get sick than other people in general.

\subsubsection{Her Mother's Lies}

The protagonist not only finds the truth of her disease, but also her mother's lies.

"I step farther into the room, shaking the pages. "It's from a doctor in Maui." I look for the name again even though I know it. "Dr. Melissa Francis. Did you meet her? "If I hadn't been watching her so closely, I might not have noticed it, but she freezes. "I met a lot of doctors in Maui, Madeline.” Her voice is tight." (Yoon, 2015: 265)

The quotation shows that the protagonist's mother is afraid and worried that her lying will be known. It is very clear that her mother is silent for a while before answering a question from her daughter.

After the protagonist searches about the truth of her disease, she meets her mother again to know about the fact. And finally she knows that her mother lied all this time. 
"She walks over to her desk and clears a space. I watch her as she examines the files, rearranging them, smoothing her hands over pages that don't need smoothing. After a while she looks up at me. "Did you take them? I know they were in here." Her voice is thick with confusion and, also, fear. And that's when I know for sure. I am not sick and I never have been." (Yoon, 2015: 275)

It shows that the protagonist's mother's lying has been already known by her daughter. She cannot deny that she has been lying all this time.

By doing any resistance, the protagonist knows the truth that her mother lies to her about her disease. Her mother's lying is because of her fear of losing Madeline after the death of her father and her brother due to SCID. This urges her mother to lies Madeline about what she suffers from.

\section{Conclusion}

Based on the analysis about the problem in the novel, the finding can be exposed. The form of resistance of the protagonist is clear to find out of the truth of her disease that her mother had been hiding so far and also to reveal lies from her mother. It is found that same in objective of the problems are to find out the forms of the protagonist's resistance in the novel and to reveal the truth found by the protagonist.

There are two forms of resistance done by the protagonist in the novel. They are resisting her mother's rules and resisting her own fear. Both are shown by many quotations from the novel. Further, such resistance is done because of one main reason, that is, to find any truth of her life.

First, the truth found in the novel is that the protagonist finally knows that she is not exposed to SCID (Severe Combined Immunodeficiency). She is just exposed to inflammation of the heart muscle because the immune system is less developed. Second, she also knows that her mother lies all this time because his mother is traumatized by the death of her father and brother. And she is afraid of losing the protagonist too.

All in all, the above analysis answers the problems of this study. The protagonist does any kind of resistance and she has any reason to do that. That is truth.

\section{References}

Aminuddin, (2002). Pengantar Apresiasi Karya Sastra. Bandung: Sinar Baru Algensindo.

Arkowitz, H. (2002). Toward an Integrative Perspective on Resistance to Change. Journal of Clinical Psycology, 58, 219-227.

Bakhtiar, Amsal. (2010). Filsafat Ilmu. Jakarta: Rajawali Pers.

Bernardo, Karen. (2001). Characterization in Literature. Retrieved from: http://learn.lexiconic.net/character.htm (September 10, 2012).

Chungho, Wing. (2011). James Scott's Resistance/Hegemony Paradigm Reconsidered. University of Hong Kong: Macmillan Publisher Ltd. 0001-6810.

Eric. S, Jay.A. (2004). Resistance and Persuasion. New Jersey: Lawrence Erlbaum Associates, Inc. (Ed).

Jujun S, Suriasumantri. (2010). Filsafat Ilmu: Sebuah Pengantar Populer. Jakarta: Pustaka Sinar Harapan.

Keraf, Sonny. (2001). Ilmu Pengetahuan: Sebuah Tinjauan Filosofis. Yogyakarta: Kanisius. 
Kusumawardani, Airien. (2016). Everything, Everything. Depok: PT. Spring.

Lorens, Bagus. (2001). Kamus Filsafat. Jakarta: PT. Gramedia Pustaka Utama.

Messer, S. B. (2002). A Psychodynamic Perspective on Resistance in Psychotherapy. Viva La Resistance. Journal of Clinical Psychology, 58, 157-163.

Moleong, Lexy J. (2014). Metodologi Penelitian Kualitatif. Bandung: PT. Remaja Rosdakarya.

Newman, C. A. (2002). A Cognitive Perspective on Resistance in Psychotherapy. Journal of Clinical Psychology, 59, 165-174.

Setiawan, Muarif, Barus, Efendi, and Pawiro, Mhd. Ali. (2017). Cause and effect of suffering in Sydney Sheldon's "If Tomorrow Comes". Language Literacy: Journal of Linguistics, Literature, and Language Teaching. Volume 1, Number 1, Desember 2017, Pages: 73-96 https://jurnal.uisu.ac.id/index.php/languageliteracy/article/view/247/236

Accessed September 2019.

Seymour, S. (2006). Resistance. Anthropological Theory 6(3): 303-321.

Sugiyono. (2009). Metode Penelitian Pendidikan. Bandung: Alfabeta.

Sugiyono. (2010). Metode Penelitian Kuantitif Kualitatif dan R\&D. Bandung: Alfabeta.

Sugiyono. (2013). Metode Penelitian Penddikan Pendekatan Kuantitif Kualitatif dan $R \& D$. Bandung: Alfabeta.

Umi, Narimawati et.al. (2011). Penulisan Karya Ilmiah, Edisi Pertama. Genesis. Bekasi: Pondok Gede.

Wahyuningtyas, Sri, and Wijaya, Heru Santosa. (2011). Sastra: Teori dan Implementasi. Surakarta: Yuma Pustaka.

Wiehardt, Ginny. (December 2018). Definition of a Protagonist in Literature, withExample.http://www.thebalancecareers.com/protagonist (December 2018).

Yoon, Nicola. (2015). Everything, Everything. New York: Delacorte Press. 